\title{
Patient participation in relation to life style changes-A literature review
}

\author{
Hanne Konradsen*, Hanne Troest Nielsen, Marianne Thrane Larsen, Carrinna Hansen \\ Gentofte Hospital, Hellerup, Denmark \\ Email: " hakon@geh.regionh.dk
}

Received 31 March 2012; revised 24 April 2012; accepted 3 May 2012

\begin{abstract}
The objective of this literature review was to identify and examine research where Patient Participation was used as a part of intervention targeting general life style among patients who comes in contact with a nurse. A literature search were conducted and included papers where judged by the researcher using recommendation from The Danish Centre for Clinical Guidelines. Analysis of the papers was carried out using Peräkylä and Ruusuvauoris five components of Patient Participation as a theoretical template. It was concluded that the clinical effects of Patient Participation still needs to be clarified.
\end{abstract}

Keywords: Patient Participation; Life Style; Review; Nursing

\section{INTRODUCTION}

WHO estimates that in 2015 around $80 \%$ of all deaths in industrialised countries are related to chronic diseases that might be mitigated through lifestyle [1]. The different domains related to lifestyle, such as smoking, overweight, exercise or others, are relevant in varying degree in relation to different diseases. Still, in relation to most diseases and their prevention, care or treatment, lifestyle is an issue that nurses have to consider in the entire patient trajectory. Nurses often play a main role in providing lifestyle advices [2], as a prevention of hospitalization [3], during hospitalization [4,5] or in relation to rehabilitation. Accordingly, many patients have to handle several lifestyle changes and nurses have an important role in supporting the patients and facilitating these changes.

Knowledge on how to work effectively with secondary prevention is sparse [6]. However, it is inevitably that it takes place in cooperation and common understanding between the health professional and the patient. It must involve patients participating in the process.

"Corresponding author.
Clayton wrote in 1988 that Patient Participation is an important part of the nursing vocabulary [7]. In a concept analysis, Sahlsten et al. concluded that Patient Participation in nursing practice can be defined as an established relationship between nurse and patient, surrender of some power or control by the nurse, shared information and knowledge, and active engagement together in intellectual and/or physical activities [8]. Cahill concluded in 1998 that most findings in relation to the value of Patient Participation were anecdotal and that there was a need to explore the concept in the reality of practice [9]. This was also found by Guadagnoli and Ward, who stated that the benefits of Patient Participation have not yet been clearly demonstrated in research studies [10].

It therefore seemed to be of interest to take a closer look at studies, where Patient Participation were said to have played a role in intervention targeted general lifestyle and not just a single lifestyle domain. This could elucidate possible clinical workable elements that might be used in future interventions.

The objective of this literature review was to identify and examine research where Patient Participation was used as a part of intervention targeting general life style among patients who comes in contact with a nurse.

\section{METHOD}

\subsection{Selection}

Empirically-based papers were identified through a literature survey in international peer-reviewed journals. The specific research question was; in intervention studies targeted life style in general, what are the specific clinical elements named Patient Participation?

To systematically describe and analyse findings, the Matrix Method [11] was chosen, which meant that information management was designed prior to abstracting data from the collected articles.

The databases Pubmed, ERIC and Cinahl were searched by the first author, from the year 2000 and forward. The main search pragmatically included the broad terms patient participation, intervention/nursing intervention 
and lifestyle change/lifestyle changes/life style intervention in different combinations. Only few papers were found, and as Patient Participation is not clearly defined, the term Patient Participation was exchanged by adjoining the concepts self efficacy and empowerment in a later search, in order to make sure that relevant papers were found.

Included were papers published in Danish, Swedish, Norwegian or English, from year 2000 and forward. The papers had to report from original interventional studies which claimed to use Patient Participation as an intervention factor and evaluate life style in general. Interventions that targeted only one specific lifestyle were excluded. The participating patients were all adults i.e., 18 years or older. There were no limits as to how the studies defined Patient Participation and no limits to clinical setting.

\subsection{Validity Assessment}

The included papers were collected and sent to all the research members, who read the included papers repeatedly. At several meetings the papers were discussed, both the actual findings and the quality of the studies which was judged using recommendations from The Danish Centre for Clinical Guidelines. According to the principles outlined in the Matrix Method each of the 5 papers were evaluated using a structured matrix with the topics: Journal identification, purpose, lifestyle factors addressed, intervention, sampling design, number of participants and results.

\subsection{Results of the Search Process}

Initially the broad literature search resulted in 76 titles, and all abstract were retrieved and read. 5 papers met the inclusion criteria (Table 1). 71 papers were excluded either because they were non-intervention, professionals' views or did not reflect lifestyle change. The studies were all published from 2006 and forward and were targeted a broad variety of lifestyle changes and clinical settings. All studies aimed at addressing more than one lifestyle. In the papers the intervention addressed patients in relation to cardiac rehabilitation, stroke prevention, hypertension, diabetes or multiple sclerosis. In relation to cardiac rehabilitation reduced systolic blood pressure were achieved and in relation to multiple sclerosis higher level of health promotion activities was achieved. Beside these no further clinical improvements were achieved. In none of the clinical studies included, Patient Participation was viewed as a single intervention; it was seen as embedded in or following a complex intervention with several different elements.

\subsection{Data Analysis}

In all of the included papers the intervention consisted of multiple components, and in order to analyse the interventions that had been used further, Peräkylä and Ruusuvauoris five components of Patient Participation were used as a theoretical template [12]. Based on empirical research they outline five key components of Patient Participation. Recognizing that the components were derived from settings of observational studies, we found them useful for our purpose. In the following the five components are described as we used them:

1) The patient's contribution to action

Within this component we searched for evidence of the way the patient participated in initiating action within the studies. Patients either initiated action which required the professional to respond, or the other way around.

2) The patients' influence in the definition of the consultations agenda

Within this component we looked for the patients' influence on the agenda in the introduction to the intervention studies. It concerns the patients' possibility to present or define the problems that they find most important in their situation.

3) Patients share in the reasoning process

Within this component we looked for the patients' opportunity to convey their relevant knowledge and their understanding regarding the problem. We looked for the extent to which the professionals and the methods used individualize problem solving in consultations.

4) Patients' influence in the decision-making

Within this component we looked for patients' possibilities of making decisions themselves in regard to i.e. setting goals or choosing direction in treatment. It was also embedded in Patient Participation that the patients had the opportunity to say no or reject suggestions and were given different choices regarding this. In the analysis we searched for descriptions of individual guidance of patients in making decisions.

5) Emotional reciprocity

This component embedded the patients' possibility of expressing their feelings and emotions. Patient Participation was expressed in the availability of room for emotional mutuality in relationships with professionals or other patients. Patient Participation in education did not occur if patients' experiences were not included. With this component we searched for descriptions of emotional relationships between patients and professionals or patients and patients.

The results are shown in Table 2.

\section{RESULTS}

\section{Components in Patient Participation}

There were no studies found with a clear theoretical approach related to Patient Participation as such.

Since all the included studies described interventions 
Table 1. Matrix included studies.

\begin{tabular}{|c|c|c|c|c|c|c|c|}
\hline & Year & Purpose & $\begin{array}{l}\text { Life style } \\
\text { addressed }\end{array}$ & Intervention & Sampling & $\begin{array}{c}\text { Number of } \\
\text { participants }\end{array}$ & Results \\
\hline $\begin{array}{l}\text { A randomized controlled } \\
\text { trial of a health promotion } \\
\text { education programme for } \\
\text { people with multiple } \\
\text { sclerosis. Ennis M. et al. } \\
\text { Clinical rehabilitation } 2006 \\
\text { 20;783-792 }\end{array}$ & 2006 & $\begin{array}{l}\text { Evaluate } \\
\text { effectiveness of a } \\
\text { health promotion } \\
\text { education } \\
\text { programme for } \\
\text { people with } \\
\text { multiple sclerosis }\end{array}$ & $\begin{array}{l}\text { Exercise, } \\
\text { fatigue, stress, } \\
\text { nutrition }\end{array}$ & $\begin{array}{l}\text { Group based eight } \\
\text { weekly sessions of } \\
3 \text { hours, "Optimize" }\end{array}$ & $\begin{array}{l}\text { Patients } \\
\text { attending a } \\
\text { multiple } \\
\text { sclerosis clinic } \\
\text { at a regional } \\
\text { neuroscience } \\
\text { center }\end{array}$ & $\begin{array}{l}61 \text { patients } \\
\text { randomised, } \\
31 \text { in } \\
\text { intervention, } \\
30 \text { in control }\end{array}$ & $\begin{array}{l}\text { Significant higher } \\
\text { levels of health } \\
\text { promotion activity } \\
\text { undertaken. }\end{array}$ \\
\hline $\begin{array}{l}\text { Education in stroke } \\
\text { prevention: Efficacy of an } \\
\text { educational counselling } \\
\text { intervention to increase } \\
\text { knowledge in stroke } \\
\text { survivors. Green T. et al. } \\
\text { Canadian Journal of } \\
\text { Neuroscience Nursing } 2007 \\
29(2) ; 13-20\end{array}$ & 2007 & $\begin{array}{l}\text { Examine impact of } \\
\text { one-to-one brief } \\
\text { nurse-patient } \\
\text { interview on } \\
\text { acquisition of } \\
\text { knowledge of stroke } \\
\text { and influence on } \\
\text { lifestyle behaviour } \\
\text { change }\end{array}$ & $\begin{array}{l}\text { Smoking, } \\
\text { exercise, } \\
\text { alcohol }\end{array}$ & $\begin{array}{l}\text { Nurse consultation } \\
\text { and lifestyle class }\end{array}$ & $\begin{array}{l}\text { Patients } \\
\text { consulting an } \\
\text { ambulatory } \\
\text { stroke } \\
\text { prevention clinic }\end{array}$ & $\begin{array}{l}200 \text { patients } \\
\text { randomised, } \\
100 \text { in } \\
\text { intervention, } \\
100 \text { in control }\end{array}$ & $\begin{array}{l}\text { No significant } \\
\text { difference between } \\
\text { groups on the } \\
\text { identified risk } \\
\text { factors }\end{array}$ \\
\hline $\begin{array}{l}\text { A quasi-experimental study } \\
\text { on a community-based } \\
\text { stroke prevention } \\
\text { programme for clients with } \\
\text { minor stroke. Sit JWH et al. } \\
\text { Journal of clinical nursing } \\
2007(16) 272-281\end{array}$ & 2007 & $\begin{array}{l}\text { Determine the } \\
\text { effectiveness of a } \\
\text { community } \\
\text { stroke-prevention } \\
\text { programme }\end{array}$ & $\begin{array}{l}\text { Stroke } \\
\text { prevention } \\
\text { issues, food, } \\
\text { smoking, blood } \\
\text { pressure }\end{array}$ & $\begin{array}{l}\text { Nursing } \\
\text { consultation (nurses } \\
\text { as facilitators), } 8 \\
\text { weekly } 2 \text { hours } \\
\text { sessions }\end{array}$ & $\begin{array}{l}\text { Participants who } \\
\text { have had a } \\
\text { minor stroke }\end{array}$ & $\begin{array}{l}190 \text { patients, } \\
107 \text { in } \\
\text { intervention, } \\
83 \text { in control } \\
\text { (randomized } \\
\text { by time slots) }\end{array}$ & $\begin{array}{l}\text { No significant } \\
\text { improvement in } \\
\text { smoking or drinking } \\
\text { alcohol, maintaining } \\
\text { exercise in } \\
\text { intervention group }\end{array}$ \\
\hline
\end{tabular}

The role of self-efficacy in vascular risk factor management: a randomized controlled trial. Sol BG, van der Graaf Y, van der Bijl JJ, Goessens BM, Visseren FL. Patient Educ Couns. 2008 May;71(2):191-7.

A pilot randomised controlled trial comparing a health-related lifestyle self-management intervention with standard cardiac rehabilitation following an acute cardiac event: Implications for a larger trial. Fernandez et al. Australian Critical Care 2009 22;17-27
Nursing intervention to promote self-efficacy and self Smoking, 2008 management patient with clinical manifest vascular Healthy Food, Nursing disease consultations

$$
\begin{array}{ll}
\text { Participants } & 236 \text { patients, } \\
\text { from a larger } & 95 \text { in } \\
\text { study } & \text { intervention, } \\
& 80 \text { in control }
\end{array}
$$

Weight, blood pressure, glucose level, cholesterol, healthy food choice, medication use

initiated by professionals, the patients' contribution to action was mainly as responders to action directed by professionals.

To some extent the agenda was set in the intervention studies we included, i.e. the life style factors addressed in the studies are chosen in advance; accordingly patients' influence on the definition of the agenda was limited. The participating patients and nurses all participated voluntarily, as expected in research based intervention. Therefore it was difficult to determine whether the participants had an influence on determining to go against the agenda of lifestyle changes. In a fixed research pro- gram consultations are organised around a fixed problem, and if the patient has a different view of the problem, exclusion from the project is likely to have taken place, even though, an emphasis on individualising the agenda was attempted. This was either in form of the participant selecting the risk factor to focus on, the participant participating in goal setting or having an individual number of contact participant and nurse in between.

To some extent screening tools and self evaluation scales were used in the included studies. In one study the patients' contribution to the direction of action was based on a professionals screening of patients' readiness to 
Table 2. Matrix components of patient participation.

\begin{tabular}{|c|c|c|c|c|c|}
\hline & $\begin{array}{l}\text { Patient contribution to } \\
\text { direction of action }\end{array}$ & $\begin{array}{l}\text { Patients influence in } \\
\text { the definition of the } \\
\text { agenda }\end{array}$ & $\begin{array}{l}\text { Patients share in the } \\
\text { reasoning process }\end{array}$ & $\begin{array}{l}\text { Patients influence in } \\
\text { the decision-making }\end{array}$ & $\begin{array}{l}\text { Emotional } \\
\text { reciprocity }\end{array}$ \\
\hline $\begin{array}{l}\text { A randomized controlled } \\
\text { trial of a health promotion } \\
\text { education programme for } \\
\text { people with multiple } \\
\text { sclerosis. Ennis M. et al. } \\
\text { Clinical rehabilitation } 2006 \\
\text { 20;783-792 }\end{array}$ & & & $\begin{array}{l}\text { Education provided } \\
\text { was specific to the } \\
\text { patients' individual } \\
\text { needs }\end{array}$ & $\begin{array}{l}\text { Theory followed by } \\
\text { practical sessions, to } \\
\text { increase opportunity for } \\
\text { patients to make } \\
\text { informed decisions. }\end{array}$ & $\begin{array}{l}\text { Opportunity for } \\
\text { making experiences } \\
\text { and verbal } \\
\text { persuasion from } \\
\text { others at group } \\
\text { settings }\end{array}$ \\
\hline $\begin{array}{l}\text { Education in stroke } \\
\text { prevention: Efficacy of an } \\
\text { educational counselling } \\
\text { intervention to increase } \\
\text { knowledge in stroke } \\
\text { survivors. Green T. } \text { et. al. } \\
\text { Canadian Journal of } \\
\text { Neuroscience Nursing } 2007 \\
\text { 29(2);13-20 }\end{array}$ & $\begin{array}{l}\text { Brief patient-specific } \\
\text { analysis of personal } \\
\text { stroke risk factors with } \\
\text { subsequent discussion } \\
\text { about risk management } \\
\text { strategies }\end{array}$ & & $\begin{array}{l}\text { Nurse and patient } \\
\text { identified health } \\
\text { behaviour needing } \\
\text { change and identified } \\
\text { barriers and } \\
\text { facilitators to change }\end{array}$ & & \\
\hline $\begin{array}{l}\text { A quasi-experimental study } \\
\text { on a community-based } \\
\text { stroke prevention } \\
\text { programme for clients with } \\
\text { minor stroke. Sit JWH et al. } \\
\text { Journal of clinical nursing } \\
2007(16) 272-281\end{array}$ & & $\begin{array}{l}\text { Participants select the } \\
\text { risk factor on which to } \\
\text { focus, }\end{array}$ & $\begin{array}{l}\text { Promote individual } \\
\text { reflection }\end{array}$ & $\begin{array}{l}\text { Sessions closed with a } \\
\text { word of commitment } \\
\text { from each participant } \\
\text { Participants setting } \\
\text { practical short term } \\
\text { goals }\end{array}$ & $\begin{array}{l}\text { Sharing of } \\
\text { experiences in } \\
\text { group, feedback in } \\
\text { group }\end{array}$ \\
\hline $\begin{array}{l}\text { The role of self-efficacy in } \\
\text { vascular risk factor } \\
\text { management: a randomized } \\
\text { controlled trial. Sol BG, van } \\
\text { der Graaf Y, van der Bijl JJ, } \\
\text { Goessens BM, Visseren FL. } \\
\text { Patient Educ Couns. } 2008 \\
\text { May; 71(2):191-7. }\end{array}$ & $\begin{array}{l}\text { Patients were } \\
\text { encouraged to active } \\
\text { participation and } \\
\text { self-management by } \\
\text { promoting self efficacy }\end{array}$ & $\begin{array}{l}\text { Individual guidance in } \\
\text { relation to risk factors } \\
\text { Individual number of } \\
\text { contacts }\end{array}$ & $\begin{array}{l}\text { The patients earlier } \\
\text { experiences and } \\
\text { motivation for change } \\
\text { are discussed }\end{array}$ & $\begin{array}{l}\text { Patients encouraged to } \\
\text { set individual reachable } \\
\text { goals } \\
\text { Self-evaluation at } \\
\text { follow-up visits }\end{array}$ & $\begin{array}{l}\text { Encouraged to bring } \\
\text { a relative or partner } \\
\text { when visiting the } \\
\text { clinic }\end{array}$ \\
\hline $\begin{array}{l}\text { A pilot randomised } \\
\text { controlled trial comparing a } \\
\text { health-related lifestyle } \\
\text { self-management } \\
\text { intervention with standard } \\
\text { cardiac rehabilitation } \\
\text { following an acute cardiac } \\
\text { event: Implications for a } \\
\text { larger trial. Fernandez et al. } \\
\text { Australian Critical Care } \\
2009 \text { 22;17-27 }\end{array}$ & $\begin{array}{l}\text { Tailored information } \\
\text { according to stage of } \\
\text { change }\end{array}$ & $\begin{array}{l}\text { Patients were asked to } \\
\text { write down specific } \\
\text { and realistic goals they } \\
\text { would like to achieve }\end{array}$ & $\begin{array}{l}\text { Self identification of } \\
\text { risk factors with } \\
\text { personal professional } \\
\text { feed-back }\end{array}$ & $\begin{array}{l}\text { The patients sets the } \\
\text { goal }\end{array}$ & $\begin{array}{l}\text { Supportive } \\
\text { individual } \\
\text { telephone calls }\end{array}$ \\
\hline
\end{tabular}

change. The stages of change model, including five stages of change: pre-contemplation, contemplation, preparation, action and maintenance, was used related directed toward all of the specific lifestyle issues. In one study, related to vascular risk factor management, the patients' were encouraged to active participation by promoting self efficacy.

Individual identification of health behaviour that needed change, promotion of reflection related to the change and its barriers and facilitators and professional feed-back were elements that were used as overall frame in all of the studies.
In three of the papers patients were encouraged to set their own goals for life style changes. A surrendering of control from the health care provider to the patient was therefore established; on the other hand all of the studies might have had the goal to engage healthcare provider and patient in mutual intellectual activity.

Emotional reciprocity was described as group sharing of experiences, follow-up telephone calls, encouraging bringing a relative or the nurses using open questions and mutual summarising. Establishment of a relationship between patient and healthcare provider was only described in terms of interactions and not in terms of de- 
veloping a relationship over time.

\section{DISCUSSION}

Conducting the search for intervention that stated to use Patient Participation as an intervention strategy revealed a limited number of studies. If the value of the concept Patient Participation in relation to lifestyle intervention in a broad sense is to move beyond anecdotal or a theoretical and ethical purpose, more studies are needed.

Sahlsten et al. found that establishing a relationship between patient and professional has been described as an important component, and that the concept Patient Participation has component of surrendering some kind of power, sharing of information and knowledge [8]. This was to some extent also found in the studies in this review, in that patient and not professional setting goals for life style changes seemed important in four papers. In a study by Lane [13], the lessons learned included handing over some kind of control of the consultation from the nurse. An overview related to patient safety showed that Patient Participation is affected by both patient-related factors, such as acceptance of a new patient role, lack of confidence and willingness to participate in the health care process and health professional-related factors such as desire to maintain control and training in patient-caregiver relations [14]. This might point that increased Patient Participation implies both patients being able and willing to take action and professionals being able and willing to let go. A condition called congruence between desired and allowed participation [15].

In the studies in this review, patients participated in a fixed research program, but an individualisation of the agenda was attempted. It seems as if the possibility of creating individualised patient trajectories might increase the possibility for Patient Participation. This was supported by Eldh et al., who found that conditions for patient experiences of participation were; no standard procedures but based on individual needs and accompanied by explanations, when the patient was regarded as an individual, when the patient's knowledge was recognised by staff, or when the patient made decisions based on knowledge and needs [16].

In this review it was found that most studies supported the use of some kind of screening tool to evaluate the patients' readiness to change. Several studies have pointed at specific time points in the patients' trajectory that might enhance a patients desire to change life style. In example having to undergo surgery might be a "teachable moment” for smoking cessation [17]. Thereby the nurse might proactively be able to predict point in time where the patient's desire to participate in changing life habits is at the highest, which again might imply that a patient's level of readiness for change is not stable but changing through the patient trajectory. Teachable moments through a patient's trajectory might not even be unpredictable, but creatable [18], and linked to patients recall of health behaviour advice [19]. Even though, a resent review showed a lack of evidence supporting one approach over another in order to enhance patient participation in the consultation process [20].

The limited number of studies found in this review may be connected to nurses often directing their attention towards measuring expected outcomes, more than exploring alternatives through dialogue and encouraging patients to set goals and plan actions that suit the individual needs and possibilities [21]. A study on the desire for a participative role in decisions about medical problem, found that shared decision making may require a trusting relationship [22]. One study that used shared decision making in intervention targeted life style changes was found, also in this study no significant change was found [23].

In a nurse-led clinic for chronic heart failure, the patient's experience of non-participation for patients was that health care professional could overrule, but for nurses, non-participation reflected the fact that the patients did not accept what was offered them [24]. Surprisingly, in the present review, none of the studies measured whether the patients felt that they were involved in the actual decision-making process.

Patient centred care and increased Patient Participation has been shown to be an important factor in increasing adherence and clinical outcome [25,26]. A Cochrane review concluded that interventions targeting hospitalized patients including high intensity behavioural intervention and include at least one month of supportive contact after discharge promote smoking cessation, regardless of the admitting diagnosis [27]. Together this might point at the possibility that participation is something that is a process over time, and not merely connected to a single point in time.

\section{LIMITATIONS}

The process of selecting papers for this review encountered challenges in choosing relevant search terms. Patient Participation is a term closely connected and maybe even overlapping term such as: shared care, shared decision making, patient centred care, partnership and many more. The difficulties in clearly separating concepts means that studies with a less clear explanation of intervention might have been overlooked.

\section{CONCLUSION}

This literature review shows that the clinical effects of Patient Participation in promoting lifestyle changes still need to be clarified in order to move beyond being 
anecdotal.

\section{REFERENCES}

[1] World Economic Forum (2008) Working towards wellness: The business rationale. https://members.webforum.org/pdf/Wellness/Bus-Rationa le.pdf

[2] Holtrop, J.S., Baumann, J., Arnold, A.K. and Torres, T. (2008) Nurses as practice change facilitators for healthy behaviours. Journal of Nursing Care Quality, 23, 123131. doi:10.1097/01.NCQ.0000313761.79396.37

[3] Kaila-Kangas, L., Leino-Arjas, P., Riihimaki, H., Luukkonen, R. and Kirjonen, J. (2003) Smoking and overweight as predictors of hospitalization for back disorders. Spine, 28, 1860-1868.

[4] Sari, N. (2010) A short walk a day shortens the hospital stay: Physical activity and the demand for hospital services for older adults. The Canadian Journal of Public Health, 101, 385-389.

[5] Sadr, A.O., Bellocco, R., Eriksson, K. and Adami, J. (2006) The impact of tobacco use and body mass index on the length of stay in hospital and the risk of post-operative complications among patients undergoing total hip replacement. Journal of Bone \& Joint Surgery, 88, 1316-1320. doi:10.1302/0301-620X.88B10.17957

[6] Andersson, A., Sundel, K.L., Undén, A.L., SchenckGustafsson, K. and Eriksson, I. (2010) A five-year rehabilitation programme for younger women after a coronary event reduces the need for hospital care. Scandinavian Journal of Public Health, 38, 566-573.

doi:10.1177/1403494810377125

[7] Clayton, S. (1988) Patient participation: An under-developed concept. Journal of the Royal Society for the Promotion of Health, 108, 55-56. doi:10.1177/146642408810800207

[8] Sahlsten, M.J.M., Larsson, I.E., Sjöström, B. and Plos, K.A.E. (2008) An analysis of the concept of patient participation. Nursing Forum, 43, 2-11. doi:10.1111/j.1744-6198.2008.00090.x

[9] Cahill, J. (1998) Patient participation-A review of the literature. Journal of Clinical Nursing, 7, 119-128. doi:10.1046/j.1365-2702.1998.00132.x

[10] Guadagnoli, E. and Ward, P. (1998) Patient participation in decision-making. Social Science \& Medicine, 47, 329339. doi:10.1016/S0277-9536(98)00059-8

[11] Garrad, J. (2011) Health sciences literature review made easy: The matrix method. Jones and Bartlett, Sudbury.

[12] Peräkylä, A. and Ruusuvuori, J. (2007) Components of participation in health care consultations; a conceptual model for research. In: Sbnrjta, C. Ed., Patient Participation in Health Care Consultations. Qualitative Perspectives, Open University Press, Maidenhead, 167175.

[13] Lane, C., Johnson, S., Rollnick, S., Edwards, K. and Lyons, M. (2003) Consulting about lifestyle change: Evaluation of a training course for specialist diabetes nurses. Practical Diabetes International, 20, 204-208. doi:10.1002/pdi.503

[14] Longtin, Y., Sax, H., Leape, L.L., Sheridan, S.E., Donaldson, L. and Pittet, D. (2010) Patient participation: Current knowledge and applicability to patient safety. Mayo Clinic Proceedings, 85, 53-62. doi:10.4065/mcp.2009.0248

[15] Schoot, T., Proot, I. and Meulen, R.T. and De Witte, L. (2005) Actual interaction and client centeredness in home care. Clinical Nursing Research, 14, 370-393. doi:10.1177/1054773805280093

[16] Eldh, A.C., Ekman, I. and Ehnfors, M. (2006) Conditions for patient participation and non-participation in health care. Nursing Ethics, 13, 503-514. doi:10.1191/0969733006nej8980a

[17] Shi, Y. and Warner, D.O. (2010) Surgery as a teachable moment for smoking cessation. Anesthesiology, 112, 102107. doi:10.1097/ALN.0b013e3181c61cf9

[18] Lawson, P.J. and Flocke, S.A. (2009) Teachable moments for health behaviour change: A concept analysis. Patient Education and Counseling, 76, 25-30. doi:10.1016/j.pec.2008.11.002

[19] Flocke, S.A. and Stange, K.C. (2004) Direct observation and patient recall of health behaviour advice. Preventive Medicine, 38, 343-349. doi:10.1016/j.ypmed.2003.11.004

[20] Haywood, K., Marshall, S. and Fitzpatrick, R. (2006) Patient participation in the consultation process: A structured review of intervention strategies. Patient Education and Counseling, 63, 12-23. doi:10.1016/j.pec.2005.10.005

[21] Smith, A.S. (1995) Patient participation in changing behaviours. Home Healthcare Nurse, 13, 45-49. doi:10.1097/00004045-199503000-00007

[22] Kraetschmer, N., Sharpe, N., Urowitz, S. and Deber, RB. (2004) How does trust affect patient preferences for participation in decision-making? Health Expect, 7, 317-326. doi:10.1111/j.1369-7625.2004.00296.x

[23] Koelewijn-van Loon, M.S., Van der Weijden, T., Ronda, G., Van Steenkiste, B., Winkens, B., Elwyn, G., et al. (2010) Improving lifestyle and risk perception through patient involvement in nurse-led cardiovascular risk management: A cluster-randomized controlled trial in primary care. Preventive Medicine, 50, 35-44. doi:10.1016/j.ypmed.2009.11.007

[24] Eldh, A.C., Ehnfors, M. and Ekman, I. (2006) The meaning of patient participation for patients and nurses at a nurse-led clinic for chronic heart failure. European Journal of Cardiovascular Nursing, 5, 45-53. doi:10.1016/j.ejcnurse.2005.06.002

[25] Loh, A., Leonhart, R., Wills, C.E., Simon, D. and Harter, M. (2007) The impact of patient participation on adherence and clinical outcome in primary care of depression. Patient Education and Counseling, 65, 69-78. doi:10.1016/j.pec.2006.05.007

[26] Robinson, J.H., Callister, L.C., Berry, J.A. and Dearing, K.A. (2008) Patient-centered care and adherence: Definitions and applications to improve outcomes. Journal of the American Academy of Nurse Practitioners, 20, 600- 
607. doi:10.1111/j.1745-7599.2008.00360.x

[27] Rigotti, N.A., Munafo, M.R. and Stead, L.F. (2007) In- terventions for smoking cessation in hospitalised patients. Cochrane Database of Systematic Reviews, 3, CD001837. 